\title{
Effects of tampon components on growth and dissemination of Neisseria gonorrhoeae
}

\author{
R J ARKO, K H WONG, K G FINLEY-PRICE, AND J K RASHEED \\ From the Center for Infectious Diseases, Center for Disease Control, Atlanta, Georgia, USA
}

SUMMARY Six components used in vaginal tampons were tested for their effects on a strain of Neisseria gonorrhoeae isolated from a patient with disseminated infection. Tampon components containing carboxymethyl cellulose or its derivative prolonged the in-vitro survival of gonococci and, when injected with mucin into mice, significantly $(\mathrm{P}<0 \cdot 0001)$ increased the dissemination of gonococci from the peritoneal cavity. In contrast, a component extracted from rayon tampons reduced in-vitro survival and appeared to suppress gonococcal dissemination in mice. Since tampons are used by a large number of women at a time when the risk of developing complications from venereal infections are increased, their effects on potential urogenital pathogens warrant further study.

\section{Introduction}

The association of toxic shock syndrome (TSS) in menstruating women with vaginal Staphylococcus aureus and the use of tampons ${ }^{1-3}$ has stimulated interest in determining the biological effects of various tampon components on other pathogens associated with the female reproductive tract. The use of intrauterine contraceptive devices (IUCDs) has already been identified as a risk factor for women in developing pelvic inflammatory disease (PID) due to ascending infections with Neisseria gonorrhoeae, Chlamydia trachomatis, and possibly other pathogens. ${ }^{4-6}$ Menstruation also appears to increase the risk of complications of PID and disseminated gonococcal infection (DGI). Whether this is due to physiological changes accompanying menses or to a combination of intrinsic and extrinsic factors, such as IUCDs and tampons, remains to be determined. ${ }^{47}$ This study was undertaken to determine the effects of selected tampon components on in-vitro growth and survival and on in-vivo dissemination of $N$ gonorrhoeae in laboratory animals.

\section{Materials and methods}

BACTERIA

A strain of $N$ gonorrhoeae isolated from the joint fluid of a patient with DGI was used for testing

Address for reprints: Dr R J Arko, Building 1, Room 3254, Center for Disease Control, Atlanta, Georgia 30333, USA

Accepted for publication 29 October 1981 tampon materials. Stock cultures of this strain were frozen at $-60^{\circ} \mathrm{C}$ until streaked on to a GC base medium supplemented with $1 \%$ IsoVitalex (BBLMicrobiology Systems, Cockeysville, MD). After incubation at $36^{\circ} \mathrm{C}$ for 20 hours in a candle-extinction $\mathrm{jar}$, the gonococci were harvested with a cotton swab into sterile phosphate-buffered $\left(0.067 \mathrm{~mol} / 1 \mathrm{KH}_{2} \mathrm{PO}_{4}\right.$ and $\mathrm{Na}_{2} \mathrm{HPO}_{4}$ ) saline (PBS), pH 7.4. A spectrophotometer set at $540 \mathrm{~nm}$ was used to adjust cell suspensions to an optical transmittance of $50 \%$. Serial 10-fold dilutions of the cell suspension were then quantitated in colony-forming units (cfu) by plate counts. The cell suspensions for inoculating animals contained gonococci from $10^{5}$ to $10^{8} \mathrm{cfu} / \mathrm{ml}$.

\section{TAMPONS}

Two commercial tampons* and six tampon component materials were tested. The Rely tampon (lot 15501A16A, Proctor and Gamble, Cincinnati, Ohio) and the Tampax Super Plus tampon (lot 6T072T, Tampax Inc, Palmer, Mass) were purchased from local stores. Components of the tampons tested included: from Rely tampons (a) cross-linked derivative of carboxymethyl cellulose (CLD-CMC) and (b) polyester foam pieces; from Tampax tampons (a) powdered carboxymethyl cellulose (CMC) 'Aqualon', (b) rayon 8285, (c) 'Fiber-T-/ $\mathrm{MV} / \mathrm{CL} /$ Comber/Aqualon', and (d) 'Fiber-T-/MV/ $\mathrm{CL} /$ Comber.'

\footnotetext{
* Use of trade names and commercial sources is for identification only and does not constitute endorsement by the Public Health
} Service or by the US Department of Health and Human Services. 
IN-VITRO TESTS

\section{Tampon components}

Aqueous suspensions containing 1-2\% (wt/vol) of tampon material were prepared in PBS pH 7.4 and tested for inhibitory activity to $N$ gonorrhoeae. Suspensions were tested both before and after filtration through a Millipore membrane with a porosity of $0 \cdot 22 \mu$ (Millipore Co, Bedford, Mass). Nonfiltered suspensions were also tested after being boiled for 30 minutes. Drops of $0.05 \mathrm{ml}$ of tampon suspensions were absorbed into areas of about $1.0 \mathrm{~cm}$ in diameter on GC base plates or suspensions were pipetted into wells $(5.0 \mathrm{~mm}$ in diameter) cut into the agar surface. A lawn of $10^{4} \mathrm{cfu}$ of gonococci suspended in $0.05 \mathrm{ml}$ of PBS was then streaked over the prepared plates. After incubation for 20 hours the plates were examined under a stereoscopic microscope to determine the growth pattern in the presence and absence of the tampon suspension.

\section{Whole tampons}

The leachability and pH of Rely (CLD-CMC) and Tampax Super Plus (Rayon 8285) tampons were determined after suspending each tampon in $50.0 \mathrm{ml}$ of PBS, $\mathrm{pH} 7 \cdot 4$. The turbidity imparted by material leached from each tampon was measured at $1 / 2$-hour, $11 / 2$-hour, and three-hour intervals with a spectrophotometer set at $540 \mathrm{~nm}$. Tampons were also compared for their effects on the attachment of mouse peritoneal macrophages and on the survival of gonococcal cells. For these tests, tampons were suspended in glass containers with $100 \mathrm{ml}$ of Hanks

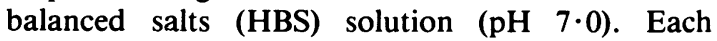
tampon was tested in triplicate along with HBS controls (without tampon). Mouse macrophages, collected by intraperitoneal lavage of mineral oilprimed mice, were washed in HBS and then added ( $10^{5}$ cells) to each tampon and control suspension. The number of macrophages remaining 'free' in each suspension was determined by cell counts made at

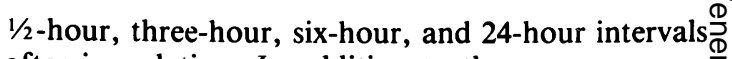
after inoculation. In addition to the mouse macrophages, $10^{8} \mathrm{cfu}$ of $N$ gonorrhoeae were added to each suspension. Survival of $N$ gonorrhoeae was determined by sequential cultures made from $0.05-\mathrm{ml} \stackrel{\text { s. }}{9}$ aliquots of each suspension at three-hour, six-hour, and then 24-hour intervals until no growth was obtained.

IN-VIVO TESTS

The ability of tampon materials to enhance or suppress the circulatory dissemination of gonococci was tested in a mouse intraperitoneal infection $\vec{\omega}$ model. ${ }^{8-10}$ Granular mucin and bovine haemoglobin were prepared as described ${ }^{8}$ and included in the $\stackrel{\text { ? }}{=}$. challenge inoculum where indicated. The challenge $\mathcal{O}_{\infty}$ inocula were prepared as follows: (a) $9.3 \mathrm{mg}$ of i mucin (type 1701-W, Wilson Laboratories, Chicago, $\vec{\circ}$ III) and $3.3 \mathrm{mg}$ of haemoglobin (Difco Laboratories, Detroit, Michigan) were mixed with gonococci and음 tampon materials in a final volume of $0.5 \mathrm{ml} / \mathrm{chal}-\rightarrow$ lenge dose; (b) $16.6 \mathrm{mg}$ of mucin was mixed with $\frac{}{0}$ gonococci and tampon materials. Immediately after mixing, the inocula were injected intraperitoneally $\vec{\bullet}$ into 3-6-week-old Institute of Cancer Research (ICR) white mice. Twenty-four hours later the challenged $\square$ mice were narcotised by inhalation of $\mathrm{CO}_{2}$, and $0.2 \mathrm{ml}$ of heart blood was aspirated from each. Approximately $0.1 \mathrm{ml}$ of each specimen was immedi-a ately streaked on to plates of GC base medium. After incubation in a candle jar for 24 hours, each plate was examined and the approximate number of cfu of gonococcal growth noted (tables I and II).

\section{ANALYSIS OF DATA}

The infectious dose $50 \%\left(\mathrm{ID}_{50}\right)$ was determined by interpolation between doses of gonococci giving less than and greater than $50 \%$ positive blood culture results. Statistical comparisons were made by the $\chi^{2} \delta$ test. ${ }^{11}$

TABLE I Effects of tampon components on dissemination of Neisseria gonorrhoeae in mice challenged intraperitoneally

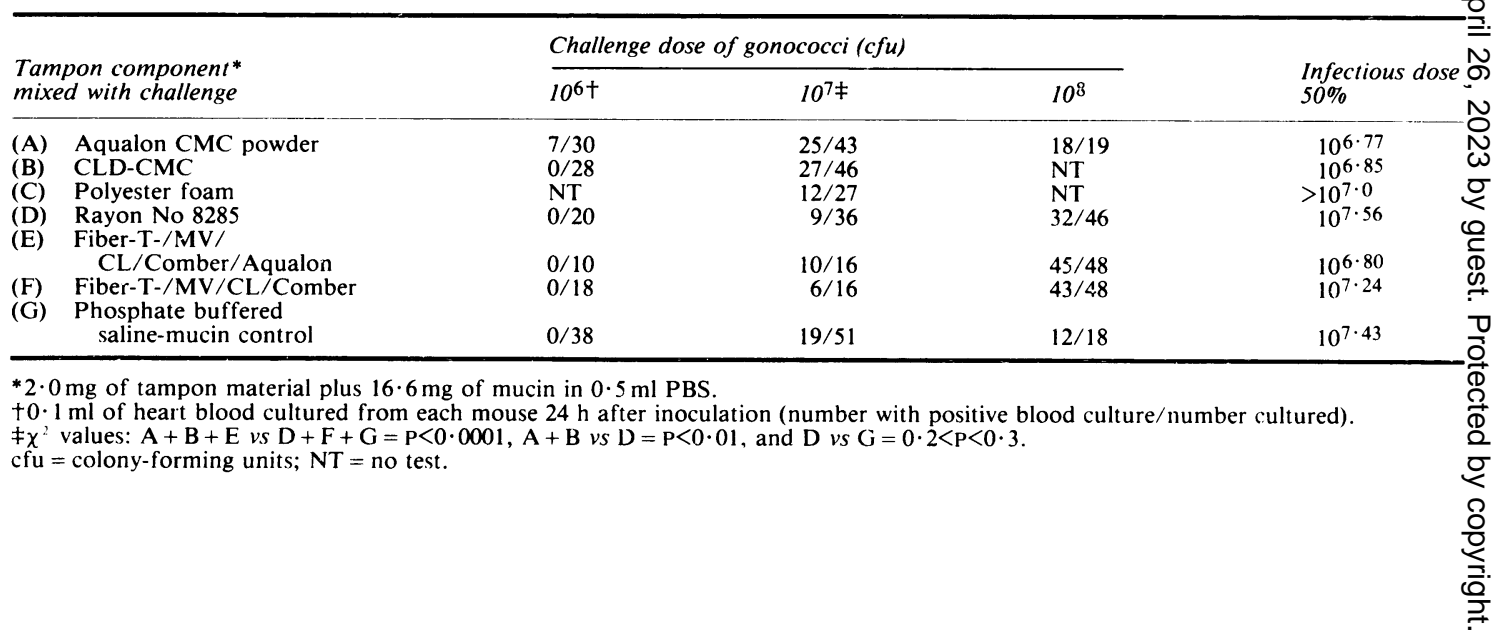


TABLE II Effects of tampon components on mortality and gonococcal bacteraemia in mice given intraperitoneal inoculations

\begin{tabular}{|c|c|c|c|c|c|c|}
\hline \multirow{2}{*}{$\begin{array}{l}\text { Inoculum } \\
\text { components* }\end{array}$} & \multirow[b]{2}{*}{$\%$ Mortality $\dagger$} & \multirow[b]{2}{*}{ No cultured } & \multicolumn{4}{|c|}{$\begin{array}{l}\text { \% Mice having indicated cfu of gonococci per } \mathrm{ml} \text { of } \\
\text { blood } \neq\end{array}$} \\
\hline & & & 0 & $1-400$ & $401-800$ & $>800$ \\
\hline \multirow{5}{*}{$\begin{array}{l}\text { PBS diluent control } \\
\text { CLD-CMC } \\
\text { Bovine haemoglobin } \\
\text { plus mucin } \\
\text { CLD-CMC plus bovine } \\
\text { haemoglobin and mucin }\end{array}$} & 0 & 26 & 100 & 0 & 0 & 0 \\
\hline & 0 & 32 & 69 & 25 & 3 & 3 \\
\hline & 23 & 54 & 50 & 39 & 2 & 9 \\
\hline & & & & & & \\
\hline & 25 & 76 & 25 & 34 & 8 & 33 \\
\hline
\end{tabular}

*Inoculum $(0 \cdot 5 \mathrm{ml})$ contained: $10^{7} \mathrm{cfu}$ of $N$ gonorrhoeae, $2 \cdot 0 \mathrm{mg}$ of cross-linked derivative of carboxymethyl cellulose (CLD-CMC), 3.3 mg of bovine haemoglobin, $9 \cdot 3 \mathrm{mg}$ gastric mucin suspended in phosphate-buffered saline (PBS), pH 7.4, PBS substituted for components not in cach test.

tMice dying in $<24 \mathrm{~h}$ and not cultured.

\#Approximately $0.1 \mathrm{ml}$ of heart blood cultured for $N$ gonorrhoeae $24 \mathrm{~h}$ after inoculation.

\section{Results}

Aqueous extracts of tampons or their components showed significant variation in their effects on the growth, survival, and in-vivo dissemination of $N$ gonorrhoeae. Inocula containing mucin plus tampon components of CLD-CMC or Aqualon CMC produced significantly $(P<0.0001)$ higher rates of gonococcal bacteraemia in mice than in mucin controls and in groups not receiving CMC (table I). The CLD-CMC component when combined with mucin and haemoglobin produced a significantly $(\mathrm{P}<0.001)$ higher systemic gonococcal infection in mice than did control inocula without CLD-CMC (table II). Rayon extracts appeared to suppress the in-vivo dissemination of $\mathrm{N}$ gonorrhoeae in the mouse model. Significantly fewer $(\mathrm{P}<0.01)$ mice in group $\mathrm{D}$ (rayon 8285) developed bacteraemia than did those in groups $\mathrm{A}$ and $\mathrm{B}$ receiving $\mathrm{CMC}$ or its derivative (table I). Although fewer mice in group D $(9 / 36)$ became bacteraemic than in group G (PBS-mucin controls, 19/51), this difference was not significant $(\mathrm{P} 0 \cdot 2<\mathrm{P}<0 \cdot 3)$.

When rayon and CLD-CMC tampons were compared for leachability and $\mathrm{pH}$, and for their effects on gonococci and the attachment of mouse macrophages, (a) CLD-CMC tampons produced substantially higher levels of turbidity in suspensions with PBS; percentage optical transmittance ranged from 20-23\% with CLD-CMC tampons compared with $\mathbf{7 9 - 9 1 \%}$ for rayon tampons and $100 \%$ for PBS controls; (b) suspensions of rayon tampons were slightly more acid, $\mathrm{pH} 6 \cdot 7$ compared with $\mathrm{pH} 7 \cdot 0$ for CLDCMC tampons; (c) by indirect determinations macrophages appeared to attach more rapidly to the rayon tampons (figure, a); and (d) gonococci remained viable for a substantially shorter period in suspension with rayon tampons than in the control HBS or CLD-CMC suspensions (figure, $b$ ). In addition, gonococci growing on a translucent medium showed phenctypic changes in morphology from smooth transparent to granular opaque colonies in areas where the rayon extract had been absorbed. A similar predominance of opaque colonies occurred around agar wells containing the rayon extract.

The factor(s) in rayon extracts producing the effects on gonococcal cells appeared to be heat stable, resisting boiling for 30 minutes, and were filterable through a $0 \cdot 22-\mu$ Millipore membrane. Analysis of these extracts by gas-liquid chromatography failed to detect fatty acids (C W Moss, unpublished data).

\section{Discussion}

The purpose of this study was to determine the biological effects and possible mechanisms whereby tampon materials may influence the growth and dissemination of $N$ gonorrhoeae. Several mechanisms potentially affecting the virulence of gonococci became apparent. (a) The CMC components appeared more soluble in aqueous fluids and had a greater tendency to leach out of the tampon into the surrounding fluid, possibly producing conditions favourable to the survival of gonococci. (b) The wrapped CLD-CMC tampons appeared to provide a less effective surface for the attachment of macrophages than did the non-wrapped rayon tampon. This could conceivably leave a greater number of macrophages engorged with gonococci after removal of the tampon from the vagina. The intracellular survival of gonococci in macrophages may thus act as a 'Trojan horse' for the dissemination of the infection across otherwise impregnable tissues. ${ }^{12}$ (c) Certain tampon components may inhibit or alter the growth of gonococci, rendering cells more susceptible to host defences. Cells from rough or opaque 

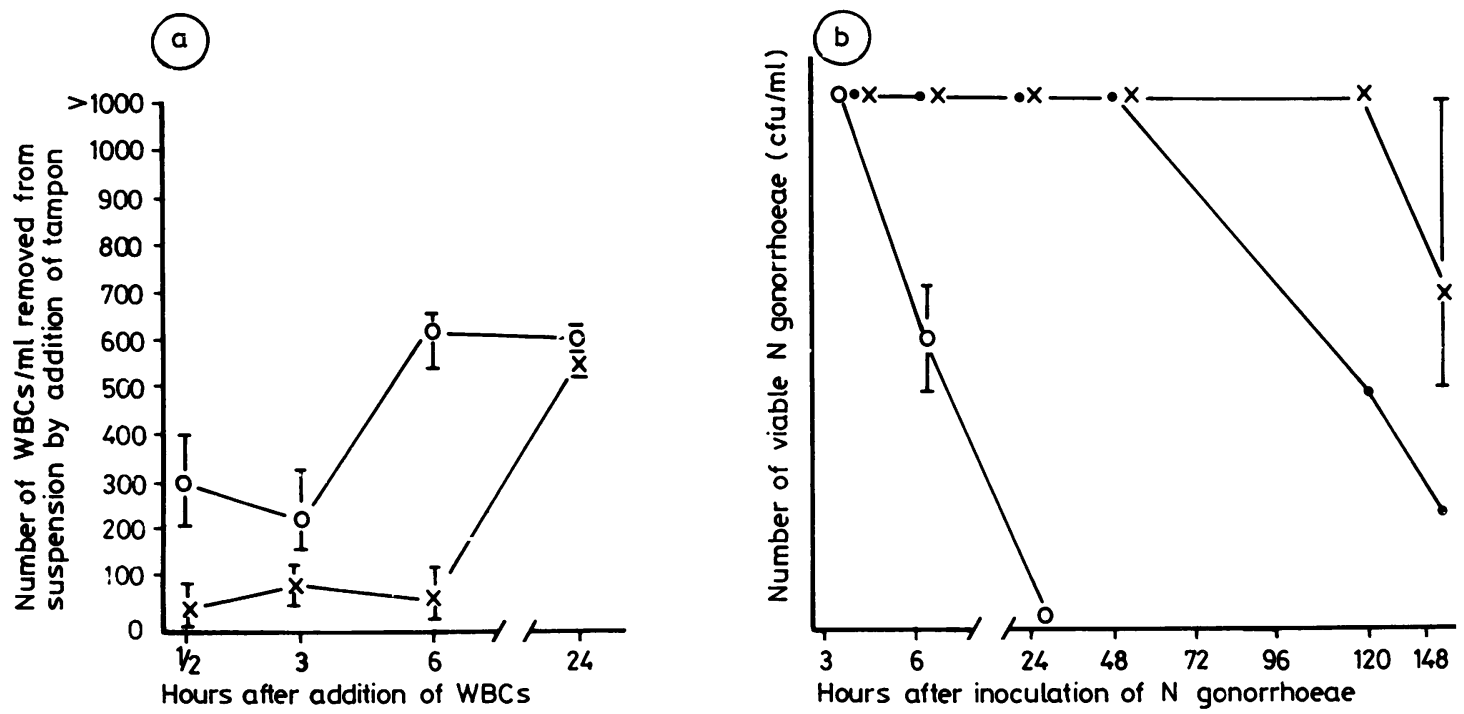

FIGURE Comparison of non-wrapped rayon tampon (O) with one of wrapped cross-linked derivative of carboxymethyl cellulose $(X)$ for effects on (a) attachment of mouse macrophages (WBC) and (b) survival of Neisseria gonorrhoeae in tampon fluid ( - $\bullet$ diluent control, $100 \mathrm{ml}$ of Hanks balanced salt solution).

colonies, similar to those induced by rayon extracts, can be approximately four times less resistant to normal human serum than cells of smooth or transparent colories. ${ }^{13}$

The practical implications of these differences in promoting or inhibiting the dissemination of $N$ gonorrhoeae by tampon materials remains to be ascertained. The effects of tampons on pathogenic micro-organisms in the vagina, however, warrants further study because a number of serious disease complications may arise from this anatomical site.

The authors thank D C Mackel, R L Anderson, and members of the CDC toxic shock task force for helpful discussion; W O Schalla for technical help; and S J Smith for statistical advice.

\section{References}

1. Davis JP, Chesney PJ, Wand PJ, et al. Toxic shock syndrome: epidemiologic features, recurrence, risk factors, and prevention. N Engl J Med 1980; 303: 1429-35.
2. Shands KN, Schmid GP, Dan BB, et. al. Toxic-shock syndrome in menstruating women: its association with tampons use and Staphylococcus aureus and the clinical features in $52 \supset$ cases. N Engl J Med 1980; 303: 1436-42.

3. Todd J, Fishaut M, Kapral F, Welch T. Toxic shock syndrome associated with phage-group-1 staphylococci. Lancet 1978; ii: 1116-8.

4. Burkman RT. Intrauterine device use and risk of pelvic inflam- $\overrightarrow{\vec{A}}$ matory disease. Am J Obstet Gynecol 1980; 138:861-3.

5. Holmes KK, Counts GW, Beaty HN. Disseminated gonococcal infection. Ann Intern Med 1971;74:979-93.

6. Scott RB. Critical illness and death associated with intrauterine devices. Obstet Gynecol 1968;31:322-5.

7. Rees E, Annels EH. Gonococcal salpingitis. Br J Vener Dises $1977 ; 45: 205-15$

8. Corbeil LB, Wunderlich AC, Corbeil RR, McCutchan JA, ItoO JI jun, Brande AI. Disseminated gonococcal infection in mice Infect Immun 1979; 26: 984-90.

9. Keefer CS, Spinks WW. Studies on gonococcal infection. IV The effect of mucin on the bacteriolytic power of whole blood 3 and immune serum. J Clin Invest 1938; 17:23-30.

10. Miller CP, Hawk WD. Experimental infection of mice with

11. Snedecor GW, Cochran GW. Statistical Methods, 6th ed. Ames, Iowa: The Iowa University Press, 1967;218.

12. Novotny $P$, Short JA, Hughes $M$, et al. Studies on then mechanism of pathogenicity of Neisseria gonorrhoeae. J Medo Microbiol 1977; 10:347-65.

13. James JF, Swanson J. Color/opacity colonial variants of Neisseria gonorrhoeae and their relationship to the menstrual cycle. In: Brooks GF, Gotschlich EC, Holmes KK, Sawyer WD, Young FE, eds. Proceedings of Immunobiology of Neisseria gonorrhoeae. Washington DC: American Society fote Microbiology, 1978:338-43. 